\title{
The Urge to Merge: The Role of Governance STRUCTURES IN MERGERS AND ACQUISITIONS
}

\author{
Catherine M. Daily \\ Purdue University \\ West Lafayette, IN \\ Dan R. Dalton \\ Indiana University \\ Bloomington, IN
}

\begin{abstract}
The 1990s have witnessed merger and acquisition activity which rivals that of the 1980s "merger mania." As firms continue to consolidate either within industries or across industries it is appropriate to investigate those aspects of a target firm which might attract a bidder. The board of directors, a central decision-making body in the corporation, may provide insights into this process. This study investigates the relationship between board composition and size and the incidence of a firm being targeted for a merger or acquisition. Results of a logistic regression analysis of a matched set of target firms and firms not targeted for merger or acquisition reveal that target firms have higher proportions of independent outside directors and more total numbers of directors. Moreover, we find that target firms have greater exposure to institutional investors.
\end{abstract}

\section{Introduction}

Mergers and acquisitions continue to dominate the corporate landscape. Recent mega-mergers and acquisitions within industries such as Upjohn Co. with Pharmacia $\mathrm{AB}$ and Chase Manhattan with Chemical Bank, as well as those across industries such as Walt Disney Co. with Capital Cities/ABC, are some evidence that the "merger mania" of the 1980s has not subsided (Business Week, 1995; U.S. News \& World Report, 1995). A growing body of research focuses on the motives which drive merger and acquisition activity (e.g., Amihud \& Lev, 1978; Eckbo, 1983; Lubatkin, 1983; Roll, 1986). Thus far, however, this research has not yet provided consensus regarding the motives of bidder firms (e.g., Haunschild, 1993). An enhanced appreciation for those elements of a target firm which are attractive to a bidder firm will enable both researchers and practitioners to gain a more comprehensive understanding of the likelihood of any given firm being targeted as a merger or acquisition candidate. 
The structure of firms' board of directors may provide insight into the attractiveness of a target firm. The board of directors is central to a decision to engage in merger or acquisition activity. Ultimate approval of major strategic moves lies with firms' board of directors (D'Aventi \& Kesner, 1993; Paul, 1995). Some observers have noted that board activity may be greatest during strategic shifts such as a merger or acquisition (Lorsch \& MacIver, 1989; Zald, 1969).

While the board of directors is clearly central to merger and acquisition activity, we still know very little about its role (see e.g., D'Aveni \& Kesner, 1993; Gibbs, 1993; Haunschild, 1993; Walsh \& Kosnik, 1993 for notable exceptions). The vast majority of mergers and acquisitions research has focused on firms' management, not their boards of directors. This study expands current research by focusing on target firms' board composition and size.

One reason bidder firms may target another firm is because they expect little resistance from the target firm's board of directors (D'Aveni \& Kesner, 1993). Firms dominated by outside directors, for example, may prove quite open to negotiations should the proposed deal be valuable from a shareholder perspective. Boards dominated by target firm management may be expected to strongly resist a merger or acquisition due to fears of job loss.

We examine the extent to which board composition discriminates between those firms engaging in merger and acquisition activity as compared to those firms not targeted by bidder firms. We also consider the impact of board size. It may be that target firms are characterized by smaller boards, leaving fewer numbers of individuals with which bidder firms must negotiate. Alternatively, larger boards may be attractive to bidder firms due to the scope of linkages to a target firms' task environment.

\section{Target Firms and the Board of Directors}

There is considerable consensus in the conceptual literature that boards of directors can be most appropriately configured with a preponderance of outside directors (e.g., Zahra \& Pearce, 1989). The rationale for this preference is the expectation that outsiders, non-management directors, bring an objectivity to their role as directors not provided by insiders. This objectivity is expected to directly benefit the shareholders whom directors serve (Nussbaum \& Dobrzynski, 1987).

We recognize that there are several potential benefits to inside directors, such as their superior level of firm specific knowledge (Baysinger \& Hoskisson, 1990; Fama, 1980; Fama \& Jensen, 1983). Additionally, inside directors have been found to be effective in CEO compensation decisions (Boyd, 1994). As will be developed, however, inside directors may be subject to conflicts of interest which complicate their ability to objectively evaluate a merger or acquisition opportunity (Johnson \& Siegel, 1987). While outsider dominated boards may effectively mitigate potential conflicts of interest that insiders face 
in this situation (e.g., Fama, 1980; Mizruchi, 1983), Jauch, Martin and Osborn (1981) provide compelling evidence that insiders may experience some difficulty in separating the threat of job loss as a result of a merger or acquisition from their fiduciary responsibility to shareholders.

Recently researchers have begun investigating distinctions among outside directors. It may be that differing levels of objectivity can be expected across different categories of outside directors (e.g., Daily \& Dalton, 1994; Kosnik, 1987). Independent outside directors (hereafter referred to as outside directors) are recognized as those directors whose association to the firm is strictly a function of their role as directors. These directors are believed to be best positioned to provide objective service to the firm. Affiliated directors maintain personal or professional relationships with either the firm or firm management. These affiliations may impede the ability of the directors to be objective in their service to the firm and the firm's shareholders (e.g., Daily \& Dalton, 1994).

Board composition may yield insights into directors' predispositions regarding resisting a merger or acquisition (Gibbs, 1993; Johnson \& Siegel, 1987; Zalecki, 1993), as it has been identified as one of several dimensions of the balance of power in an organization (Finkelstein, 1992). Target firm inside directors, for example, may resist merger and acquisition opportunities due to the increased likelihood of job loss or a dramatic redefinition of job responsibilities (e.g., Gutknecht \& Keys, 1993; Jensen \& Ruback, 1983; Morck, Shleifer \& Vishny, 1988; Walsh, 1988, 1989; Walsh \& Ellwood, 1991). Inside directors' fears are apparently well-founded. Both corporate raiders and academics have commented that a primary motive in acquiring a firm is to increase firm value by replacing ineffective managers (Fama \& Jensen, 1983; Herman \& Lowenstein, 1988; Icahn, 1988; Jensen \& Meckling, 1976; Pickens, 1986). Outside directors, due to their independence from firm management; may be able to effectively control behaviors which conflict with shareholder interests (Fama \& Jensen, 1983). Moreover, we might expect outside directors to be responsive to organizational moves which benefit firm shareholders.

As a consequence of their perceived ability to control managerial opportunism and an expectation that they will have a strong shareholder orientation, target firms with outsider dominated boards may be more attractive to bidder firms than boards with alternative board configurations (e.g., D'Aveni \& Kesner, 1993). Research by Brickley and James (1987) suggests that board composition may be a significant factor in the merger and acquisition process. They found that the proportion of outside directors was significantly lower on boards of banks in states that restrict banking acquisitions as compared to those states without such restrictions. Based on their findings, Brickley and James concluded that outside directors play a major role in evaluating takeover proposals. Accordingly, we hypothesize:

Hypothesis 1: Target firms will be characterized by greater proportions of outside directors than non-target firms. 
Due to the sophisticated financing requirements and legal maneuverings inherent in the merger and acquisition process, it may be that target firms with higher proportions of outside directors who are lawyers and investment bankers may facilitate a merger or acquisition (e.g., D'Aveni \& Kesner, 1993; Kesner, Shapiro \& Sharma, 1994; Lofthouse, 1984). Bidder firms may perceive that targets with strong legal and financial representation are best able to appreciate the intricacies involved in a merger or acquisition, especially from the shareholder perspective. Accordingly, we hypothesize:

Hypothesis 2: Target firms will be characterized by greater proportions of directors who are lawyers and investment bankers than non-target firms.

Finally, the size of the board may impact the attractiveness of a target firm. Consistent with the resource function of boards (e.g., Pfeffer \& Salancik, 1978), large board size may be some indication of the variety of external constituents with which the firm must work (e.g., Chaganti, Mahajan \& Sharma, 1985; Pfeffer, 1972). In this view, directors provide critical linkages to the external environment which may enable the firm to more effectively manage its interdependencies, as well as provide access to important firm resources (e.g., Pfeffer \& Salancik, 1978; Provan, 1980; Stearns \& Mizruchi, 1993). Directors with these linkages and interdependencies may be perceived as a critical component of a successful merger or acquisition.

Whilc a larger board may enable the firm to more effectively address a broader range of constituents, it may also be less manageable from a control perspective (Chaganti et al., 1985). Moreover, a larger board is likely to be more hetcrogeneous than a smaller board, perhaps increasing the difficulty of reaching consensus when faced with a decision to engage in a merger or acquisition. Rather than serving as a means to enhance the assimilation of a target firm with the bidder, a larger board may be perceived as an obstacle due to the potential for many differing interests which must be effectively addressed in the negotiation process. Smaller boards, then, may prove more attractive to bidder firms than larger boards. Based on the lack of consistency regarding the anticipated impact of board size we hypothesize:

Hypothesis 3a: Target firms will have greater total numbers of directors than non-target firms.

Hypothesis 3b: Target firms will have fever total numbers of directors than non-target firms. 


\section{Methods}

This sample consists of 55 firms engaging in a merger or acquisition during the years 1987-1992 and a matched pair of 55 control firms. Target firms were selected from the list of top 100 announced deals reported annually by Mergers and Acquisitions. In order to ensure data availability only those firms which were publicly-traded at the time of the acquisition or merger and involved in a "traditional" merger or acquisition (i.e., one firm acquires another firm) were included (Haunschild, 1993: 573; see also Datta, 1991). Also, firms operating in regulated environments (e.g., utilities, railroads, airlines) and banks and financial institutions were excluded (Flagg, Giroux \& Wiggins, 1991; Healy, Palepu \& Ruback, 1992; Hermalin \& Weisbach, 1988).

We relied on Ward's Business Directory of U.S. Private and Public Companies to generate a set of publicly-traded control firms by matching targets on the basis of four-digit SIC codes and firm size (e.g., Daily \& Dalton, 1994; Hambrick \& D'Aveni, 1992; Kesner \& Johnson, 1990). Target firms with no comparable match listed in Ward's Business Directory of U.S. Private and Public Companies were excluded. Logistic regression analysis confirmed that matched firms did not significantly differ from target firms on the basis of firm size, as measured by the natural logarithm of sales, assets, and number of fulltime employees.

\section{Variables}

The dependent variable is dichotomous; either the firm was the target of a merger or acquisition (coded as 1) or not targeted (coded as 0 ) during the focal year. The three independent variables include: total number of directors, proportion of outside directors (directors with no discernible tie to the firm or its management other than in their service as directors) and the proportion of outside directors who are lawyers or investment bankers. These data were collected from corporate proxy statements.

Several control variables are appropriate for inclusion in these analyses. Researchers have long speculated about the liabilities of newness and size (Stinchcombe, 1965). Younger firms may be more likely to fail as a result of environmental pressures or organizational factors and may possess fewer resources than more established firms (e.g., Van de Ven, Hudson \& Schroeder, 1984), limiting their ability to protect themselves from a merger or acquisition. Larger firms typically have greater resources available which might discourage bidders from pursuing a target due to the prohibitively high costs of financing a large transaction (Morck et al., 1988) and the ability to effectively resist a bidder (Holl \& Pickering, 1988). Firm age is computed from the time the firm was founded. Firm size is the natural logarithm of sales revenues. These data were collected from Ward's Business Directory of U.S. Private and Public Companies.

We also control for firm performance in these analyses. There is some evidence that firms with abnormally low performance are more likely to become 
targets (c.g., Asquith, 1983; Bartley \& Boardman, 1986; Bradley, Desai \& Kim, 1983; Hasbrouck, 1985). Performance may indicate the availability of resources which may be needed to resist a bidder (D'Aveni \& Kesner, 1993). Relying on guidance from Flagg et al. (1991) three categories of performance indicators are included in these analyses: profitability (return on assets), liquidity (current ratio), and leverage (debt-to-equity ratio). All financial data were collected from corporate annual reports, Moody's Industrial Manual, and Moody's Over-the-Counter Manual.

Equity holdings may also impact the incidence of being targeted for a merger or acquisition. Institutional holdings and large block holdings have been the subject of previous investigation in corporate restructuring (e.g., Bethel \& Liebeskind, 1993; Johnson, Hoskisson \& Hitt, 1993). Their anticipated impact, however, is unclear. Bidding firms may be attracted to target firms with significant institutional holdings expecting institutions to sell their holdings to the highest bidder (e.g., Buchholtz \& Ribbens, 1994; Palmieri, 1986). Alternatively, institutions may support incumbent firm management (D'Aveni \& Kesner, 1993; Ikenberry \& Lakonishok, 1993). Similar rationale would apply for large block holders (individuals holding five percent or more of firm's stock). Institutional holdings are measured as the percentage of firms' stock held by institutional investors. Large block holders are captured as the percentage of firms' stock held by five percent or greater equity holders. These data were collected from Standard \& Poor's Corporation Security Owner's Stock Guide and corporate proxy statements.

\section{Analyses}

Given the dichotomous nature of the dependent variable we rely on logistic regression analysis (likelihood ratio method). This method combines aspects of hierarchical multiple regression and discriminant function analysis.

\section{Results}

Table 1 provides the descriptive statistics and inter-item correlations for the study variables. Results of the logistic regression analysis are reported in Table 2. The baseline hit-rate for these analyses is 50 percent; half of the firms were targeted, half were not. In the first step the financial, firm size, and firm age control variables were included in the analyses. As demonstrated in Table 2 , these variables do not result in a significantly improved model $(58.18$ percent hit-rate) as compared to the baseline model. While three of these five variables are independently significant, this information must be interpreted cautiously given a non-significant model.

At the next step the stock holding control variables were added. Inclusion of these variables results in an improved model, as demonstrated by the improvement chi-square (65.45 percent hit-rate). Based on the logistic coefficients we can determine that this improvement is a function of significantly greater 
Table 1

Descriptive Statistics and Inter-item Correlations

Mean s.d. (1) (2)

(3) (4)

(5)

(6) (7) (8) (9)

(1) Firm size $6.55 \quad 1.39$

(2) Firm Age

(3) Profitability

(4) Liquidity

(5) Leverage

(6) Institutional holdings

(7) Large block holdings

(8) Outside director proportion

(9) Lawyer/banker proportion

(10) Total directors

10.37 3.45
$58.97 \quad 40.32 \quad .37^{* * *}$

$.04 \quad .11 \quad .24^{*} \quad .23 *$

$\begin{array}{lllll}2.31 & 1.50 & -.39 * * * & -.11 & -.18\end{array}$

$\begin{array}{lllllll}37.67 & 158.12 & -.19 & .05 & .15 & .24 *\end{array}$

\begin{tabular}{|c|c|c|c|c|c|}
\hline 46.70 & 19.90 & $.24^{*}$ & .16 & $.24^{*}$ & .07 \\
\hline
\end{tabular}

$\begin{array}{llllllll}27.62 & 24.87 & -.30 * * * & -.18 & -.05 & -.10 & .00 & -.49 * * *\end{array}$

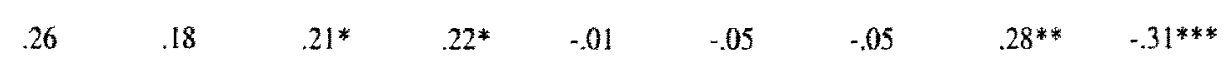

$\begin{array}{lllllll}.14 & .13 & -.19 & -.22^{*} & -.08 & .00 & -.07\end{array}$

$.33 * * *$

$-.24 * \quad-.18$

\section{.08}

$-.20^{*}$
${ }^{*} p<.05$

${ }^{* *} p<.01$

$* * * \mathrm{p}<001$ 
Table 2

Logistic Regression Analysis of Target and Non-Target Firms

Coefficients SE Log- Model Improvement Sig. Hit-rate likelihood Chi-square Chi-square

Baseline

$\underline{\text { lst Step }}$

Firm size

$-.50^{*}$

152.49

147.35

5.14

5.14

$399 \quad 58.18 \%$

Firm age

Profitability ${ }^{2}$

$-4.80^{*}$

2.22

Liquidity"

$-.29 * \quad .17$

Leverage

2nd Step

Institutional holdings"

$5.16^{* * *} \quad 1.58$

Large block holdings

3rd step

Outside director proportion

$-2,21$ *

128.13

8.59

8.59

$.035 \quad 70.00 \%$

Lawyer/banker proportion

Total directors

andicates variable was a significant indicator in the step in which it was entered.

$* p<.05$

${ }^{* *} p<.01$

$* * * p<.001$ 
exposure to institutional holdings for target firms, as compared to those firms not targeted.

The final step includes the board composition and size variables. This model results in a significant improvement chi-square and a 70 percent hitrate. It is possible to directly address the research hypotheses based on the logistic coefficients. As demonstrated in Table 2, hypotheses 1 and $3 a$ are supported. Target firms have significantly higher proportions of outside directors than do those firms not targeted. Also, target firm boards are larger than those of non-target firms, lending support to the resource view. Hypothesis two was not supported. There is no statistically significant difference in the proportion of lawyers and investment bankers serving target firms as compared to those firms not targeted. In sum, these analyses demonstrate that target firms have higher proportions of outside directors, larger numbers of directors, and greater exposure to institutional investors.

\section{Discussion}

These findings demonstrate the importance of the outside director in mergers and acquisitions. Those firms with higher proportions of outside directors are apparently more attractive to bidder firms than are firms with lower proportions of outside directors. These results may suggest that outside directors are perceived by bidder firms as being more amenable to a potential merger or acquisition; i.e., they are more willing to "make a deal." Perhaps those directors with no personal or professional ties to the firm are able to evaluate merger and acquisition opportunities based on a return-to-shareholder analysis which is not complicated with the concerns of inside directors for job security or the concerns of affiliated directors for the potential loss of business relationships.

An alternative view, however, is that outside directors are willing to "make a deal," but that the deal does not serve target firm shareholders as well as more director resistance to the merger/acquisition proposition. Attractiveness to the acquiring firm may be largely dependent on consummating a deal which best serves the interests of the bidding firm's shareholders. Perhaps the anticipated resistance by inside and affiliated directors makes a target firm less attractive to a bidding firm, but that this resistance serves to increase the purchase price - an outcome which is clearly attractive to target firm shareholders, but not to the bidding firm shareholders (Jarrell et al., 1988).

We would note, however, that target firms' board of directors have apparently been responsible to their shareholders in merger and acquisition situations. Prior research has demonstrated that excess returns, premiums averaging approximately 30 percent, are realized primarily by target firm shareholders; this same benefit is not shared by bidding firm shareholders (Jarrell, Brickley \& Netter, 1988; Jarrell \& Poulsen, 1989; Jensen \& Ruback, 1983; Zalecki, 1993).

The finding that larger boards are more attractive to bidder firms may indicate the importance of the director's resource role. These analyses may sug- 
gest that bidder firms appreciate the linkages that directors provide to firms' external environment. Given the increasing complexity of the business environment, greater numbers of directors may indicate a convenient means for gaining access to those resources most crucial for the effective functioning of the business. Access to these resources may prove critical to the long-term success of the merger or acquisition. This resource role is particularly important in light of past research which has demonstrated that financial benefits to the acquiring firm may not be immediately apparent at the time of the bid (Jarrell et al., 1988). It may be that bidder firms see the long-term potential of directors and that this dominates any short-term loss.

An interesting finding of this study is that the presence of lawyers and investment bankers does not differentiate between target and non-target firms. Past research has suggested that lawyers, in particular, would be particularly useful in negotiating a merger or acquisition agreement (e.g., D'Aveni \& Kesner, 1993). Lawyers and investment bankers arguably possess the specialized knowledge often needed in both structuring and completing a merger or acquisition agreement. It may be, however, that no statistically significant differences were found because the complexity of the environments in which most firms operate require the presence of these specialized directors. Perhaps lawyers and investment bankers are a necessity on today's corporate boards. Alternatively, it may be that bidder firms view target firm lawyers and investment bankers as one more impediment in successfully negotiating a deal. Bidder firms may view their own legal and financial counsel as the only beneficial counsel in this domain.

These results also have interesting implications regarding the role of institutional investors. Institutional investors have been the target of some criticism for reportedly supporting management, not shareholders, in the case of a conflict between management and shareholder interests (e.g., Graves, 1988; Lipton, 1987; Mieher, 1993). These results would seem to indicate the opposite; larger percentages of institutional holdings are positively associated with being targeted. As with outside directors, institutions may be perceived by bidder firms as being open to objectively reviewing the benefits to shareholders of a potential merger or acquisition. Institutions are apparently not as loyal to firm management as some critics have charged (e.g., Thompson, 1994). As with outside directors, however, there is the concern over whose shareholders most directly benefit from a merger/acquisition.

\section{Implications for Practice and Research}

The competitive environment in which firms operate today requires organizational leaders to constantly monitor means for gaining competitive advantage. The mergers and acquisitions environment makes this task challenging. Mergers and acquisitions are extending beyond consolidations across industries and are increasingly within industry consolidations (e.g., Business Week, 1995; 
U.S. News \& World Report, 1995). With much of recent merger and acquisition activity being driven by a desire to control distribution networks, firms missing the opportunity to benefit from industry consolidation are likely to be confronted by issues of organizational survival (U.S. News \& World Report, 1995; Wysocki, 1995). "Big is better" is back with a vengeance (U.S. News \& World Report, 1995: 46).

With the acceleration of merger and acquisition activity, managers may benefit from guidance on those elements of a firm's governance structure which are discussed in this study. Knowledge of the types of board configurations which attract a bidder firm may assist firm management in appropriately structuring their own board of directors and in assessing the viability of potential targets. This would be especially important for those firms seeking a "strategic" merger or acquisition, for example, in order to remain competitive in a rapidly changing environment.

Moreover, understanding the role of boards of directors in this arena is potentially time and resource saving given the recent trend toward using the proxy system to unseat unfriendly directors (Lipin, 1995). Proxy contests can consume a considerable amount of time and financial resources. Perhaps careful attention to the composition and size of potential target firm boards will provide bidding firms with valuable information regarding anticipated resistance to a proposed deal, as well as the type of resources available once the deal is consummated. Careful attention to ways in which the composition and size of a target firm's board may either save resources or provide future resources to the bidder firm may be a step toward improving the returns to bidder firm shareholders. The results of this study, coupled with the consistency of merger and acquisition activity, would suggest the need for further attention to these important governance issues.

\section{References}

Amihud, Y., and B. Lev. "Risk Reduction as a Managerial Motive for Conglomerate Mergers." Bell Journal of Economics 12 (1978): 605-617.

Asquith, P. "Merger Bids, Uncertainty, and Stockholder Returns." Journal of Financial Economics 11 (1983): 51-83.

Bartley, J. and C. Boardman. "The Replacement-cost Adjusted Valuation Ratio as a Discriminator Among Takeover Target Firms." Journal of Economics and Business 38(1), (1986): 41-55.

Baysinger, B. and R. E. Hoskisson. "The Composition of Boards of Directors and Strategic Control: Effects on Corporate Strategy." Academy of Management Review 15 (1990): $72-87$. 
Bethel, J. E. and J. Liebeskind. "The Effects of Ownership Structure on Corporate Restructuring." Strategic Management Journal 14 (1983): 15-31.

"Big!" U.S. News \& World Report (September 11, 1995): 46-48.

Boyd, B. K. "Board Control and CEO Compensation." Strategic Management Journal 15 (1994): 335-344.

Bradley, M., A. Desai and E. H. Kim. "The Rationale Behind Interfirm Tender Offers: Information or Synergy?” Journal of Financial Economics 11 (1983): 183-206.

Brickley, J. A. and C. M. James. "The Takeover Market, Corporate Board Composition, and Ownership Structure: The Case of Banking." Journal of Law and Economics 30 (1987): $161-180$.

Buchholtz, A. K. and B. A. Ribbens. "Role of Chief Executive Officers in Takeover Resistance: Effects of CEO Incentives and Individual Characteristics." Academy of Management Journal 37 (1994): 554-579.

Chaganti, R. S., V. Mahajan and S. Sharma. "Corporate Board Size, Composition, and Corporate Failures in Retailing Industry." Journal of Management Studies 22 (1985): 400-417.

Daily, C. M. and D. R. Dalton. "Bankruptcy and Corporate Governance: The Impact of Board Composition and Structure." Academy of Management Journal 37 (1994): 1603-1617.

Datta, D. K. "Organizational Fit and Acquisition Performance: Effects of Post-Acquisition Integration." Strategic Management Journal 12 (1991): 281-297.

D'Aveni, R. A. and I. F. Kesner. "Top Managerial Prestige, Power and Tender Offer Response: A Study of Elite Social Networks and Target Firm Cooperation During Takeovers." Organization Science 4 (1993): 123-151.

Eckbo, E. H. "Horizontal Mergers, Collusion, and Stockholder Wealth." Journal of Financial Economics 11 (1983): 241-274.

Fama, E. F. "Agency Problems and the Theory of the Firm." Journal of Political Economy 88 (1980): 288-307.

Fama, E. F. and M. C. Jensen. "Separation of Ownership and Control." Journal of Law and Economics 26 (1983): 301-325.

Finkelstein, S. "Power in Top Management Teams: Dimensions, Measurement, and Validation." Academy of Management Journal 35 (1992): 439-450.

Flagg, J. C., G. A. Giroux and C. E. Wiggins. "Predicting Corporate Bankruptcy Using Failing Firms." Review of Financial Economics 1 (1991): 67-78. 
Gibbs, P. A. "Determinants of Corporate Restructuring: The Relative Importance of Corporate Governance, Takeover Threat, and Free Cash Flow." Strategic Management Journal 14 (1993): 51-68.

Graves, S. B. "Institutional Ownership and Corporate R\&D in the Computer Industry." Academy of Management Joumal 31 (1988): 417 428.

Gutknecht, J. E. and J. B. Keys. "Mergers, Acquisitions and Takeovers: Maintaining Morale of Survivors and Protecting Employees." Academy of Management Executive 7(3), (1993): 26-36.

Hambrick, D. C. and R. A. D'Aveni. "Top Team Deterioration as Part of the Downward Spiral of Large Corporate Bankruptcies." Management Science 38 (1992): 1445 1466.

Hasbrouck, J. "The Characteristics of Takeover Targets and Other Measures." Joumal of Banking and Finance 9 (1985): 351-362.

Haunschild, P. R. "Interorganizational Imitation: The Impact of Interlocks on Corporate Acquisition Activity." Administrative Science Quarterly 38 (1993): 564-592.

Healy, P. M., K. G. Palepu and R. S. Ruback. "Does Corporate Performance Improve After Mergers?" Journal of Financial Economics 31 (1992): 135-175.

Hermalin, B. E. and M. S. Weisbach. "The Determinants of Board Composition." RAND Journal of Economics 9 (1988): 589-606.

Herman, E. S. and L. Lowenstein. "The Efficiency Effects of Hostile Takeovers." In Knights, Raiders, and Targets. Eds. J. C. Coffee, L. Lowenstein and R. RoseAckerman. New York: Oxford University Press, 1983.

Holl, P. and J. F. Pickering. "The Determinants and Effects of Actual, Abandoned and Contested Mergers." Managerial and Decision Economics 9 (1988): 1-19.

Icahn, C. "Icahn on Icahn." Fortune (February 29, 1988): 54-58.

Ikenberry, D. and J. Lakonishok. "Corporate Governance Through the Proxy Contest: Evidence and Implications." Journal of Business 66 (1993): 405-435.

Jarrell, G. A., J. A. Brickley and J. Netter. "The Market for Corporate Control: The Empirical Evidence Since 1980." Joumal of Economic Perspectives (Winter, 1988): 49. 68.

Jarrell, G. A. and A. B. Poulsen. "The Returns to Acquiring Firms in Tender Offers: Evidence from Three Decades." Einancial Management (Autumn, 1983); 12-19.

Jauch, L. R., T. N. Martin and R. N. Osborn. "Top Management Under Fire." Journal of Business Strategy 1(4), (1981): 33-41. 
Jensen, M. C. and W. H. Meckling. "Theory of the Firm: Managerial Behavior, Agency Costs and Ownership Structure." Journal of Financial Economics 3 (1976): 305-360.

Jensen, M. C. and R. S. Ruback. "The Market for Corporate Control: The Scientific Evidence." Journal of Financial Economics 11 (1983): 5-50.

Johnson, R. A., R. E. Hoskisson and M. A. Hitt. "Board of Director Involvement in Restructuring: The Effects of Board Versus Managerial Controls and Characteristics." Strategic Management Journal 14 (1993): 33-50.

Johnson, J. J. and M. Siegel. "Corporate Mergers: Redefining the Role of Target Directors." University of Pennsylvania Law Review 136 (1987): 315-416.

Kesner, I. F. and R. B. Johnson. "An Investigation of the Relationship Between Board Composition and Stockholder Suits." Strategic Management Journal 11 (1990): 327336.

Kesner, I. F., D. L. Shapiro and A. Sharma. "Brokering Mergers: An Agency Theory Perspective on the Role of Representatives." Academy of Management Journal 37 (1994): 703-721.

Kosnik, R. D. "Greenmail: A Study of Board Performance in Corporate Governance." Administrative Science Quarterly 32 (1987): 163-185.

"Land of the Giants." Business Week (September 11, 1995): 34-35.

Lipin, S. "More Potent Weapons Dwell in Takeover Arsenal." The Wall Street Journal (September 9, 1995): C1, C12.

Lipton, M. "Corporate Governance in the Age of Finance Corporatism." University of Pennsylvania Law Review 136 (1987): 1-72.

Lofthouse, S. "Strategy and Tactics for Resisting Take-over." Long Range Planning 17(4), (1984): 38-50.

Lorsch, J. W. and E. Maclver. Pawns or Potentates: The Reality of America's Corporate Boards. Boston: Harvard Business School Press, 1989.

Lubatkin, M. "Mergers and the Performance of the Acquiring Firm." Academy of Management Journal 8 (1983): 218-225.

Mieher, S. "Weak Force, Shareholder Activism, Despite Hoopla, Leaves Most CEOs Unscathed; Only Big, Famous Companies Draw Consistent Scrutiny of Institutional Owners a Case Study in Mississippi." The Wall Street Journal (May 24, 1993): Al.

Mizruchi, M. S. "Who Controls Whom? An Examination of the Relation Between Management and Boards of Directors in Large American Corporations." Academy of Management Review 8 (1983): 426-435. 
Morck, R., A. Shleifer and R. W. Vishny. "Characteristics of Hostile and Friendly Takeovers." In Corporate Takeovers: Causes and Consequences. Ed. A. J. Auerbach. Chicago: University of Chicago Press, 1988.

Nussbaum, B. and J. H. Dobrzynski. "The Battle for Corporate Control." Business Week (May 18, 1987): 102-109.

Palmieri, F. W. "Fiduciary Responsibilities Under ERISA in Corporate Takeovers." Journal of Corporate Taxation 13(2), (1986): 127-142.

Paul, C. E. "Scouting the M\&A Landscape for Quality Targets." Merger \& Acquisitions (March/April, 1995): 20-26.

Pfeffer, J. "Size and Composition of Corporate Boards of Directors: The Organization and its Environment." Administrative Science Ouarterly 17 (1972): 218-228.

Pfeffer, J. "Size, Composition, and Function of Hospital Boards of Directors: A Study of Organization-Environment Linkage." Administrative Science Quarterly 18 (1973): 349-364.

Pfeffer, J. and G. R. Salancik. The External Control of Organizations: A Resource Dependence Perspective. New York: Harper \& Row, 1978.

Pickens, T. B. "Professions of a Short-termer." Harvard Business Review 64(3), (1986): 75-79.

Provan, K. G. "Board Power and Organizational Effectiveness Among Human Service Agencies." Academy of Management Journal 23 (1980): $221-236$.

Roll, R. "The Hubris Hypothesis of Corporate Takeovers." Journal of Business 59 (1986): $197-216$.

Stearns, L. B. and M. S. Mizruchi. "Board Composition and Corporate Financing: The Impact of Financial Institution Representation on Borrowing." Academy of Management Journal 36 (1993): 603-618.

Stinchcombe, A. "Social Structure and Organizations." In Handbook of Organizations. Ed. J. G. March. Chicago: Rand McNally, 1965.

Thompson, L. M. "A Corporate Governance Committee of the Board." Directors \& Boards (Summer, 1994): 37-39.

Van de Ven, A. H., R. Hudson and D. M. Schroeder. "Designing New Business Startups: Entrepreneurial, Organizational, and Ecological Considerations." Journal of Management 10 (1984): 87-107.

Walsh, J. P. “Top Management Turnover Following Mergers and Acquisitions.” Strategic Management Journal 9 (1988): 173-183. 
Walsh, J. P. "Doing a Deal: Merger and Acquisition Negotiations and Their Impact Upon Target Company Top Management Turnover." Strategic Management Journal 10 (1989): $307-322$.

Walsh, J. P. and J. W. Ellwood. "Mergers, Acquisitions, and the Pruning of Managerial Deadwood." Strategic Management Journal 12 (1991): 201-217.

Walsh, J. P. and R. D. Kosnik. "Corporate Raiders and Their Disciplinary Role in the Market for Corporate Control." Academy of Management Journal 36 (1993): 671-700.

Wysocki, B. "Improved Distribution, Not Better Production is Key Goal in Mergers." The Wall Street Journal, (August 29, 1995): A1-A2.

Zahra, S. A. and J. A. Pearce. "Boards of Directors and Corporate Financial Performance: A Review and Integrative Model." Journal of Management 15 (1989): 291-334.

Zald, M. N. "The Power and Functions of Boards of Directors: A Theoretical Synthesis." American Journal of Sociology 75 (1969): 97-111.

Zalecki, P. H. "The Corporate Governance Roles of the Inside and the Outside Directors." University of Toledo Law Review 24 (1993): 831-858.

Catherine M. Daily is an Assistant Professor of Management in the Krannert Graduate School of Management, Purdue University. She received her Ph.D. degree in Strategic Management from the Graduate School of Business, Indiana University. Her research interests include corporate governance, strategic leadership, the dynamics of business failure, ownership structures, and research methods.

Dan R. Dalton is the Samuel and Pauline Glaubinger Chair and Associate Dean of the Graduate School of Business, Indiana University. He received his Ph.D. degree from University of California. His research interests include corporate governance, managerial ethics, corporate social resonsibility, and research methods. 